\title{
Micronuclei and other nuclear anomalies in buccal epithelial cells of children with chronic kidney disease
}

\author{
Banu Aykanat ${ }^{1 *}$, Gonca Cakmak Demircigil ${ }^{1 *}$, Necla Buyan² ${ }^{2}$ Esra Baskin ${ }^{4}$, Kaan Gulleroglu ${ }^{4}$, \\ Kibriya Fidan ${ }^{2}$, Umut Selda Bayrakci ${ }^{4}$, Aydin Dalgic ${ }^{3}$, Hamdi Karakayali ${ }^{5}$, Mehmet Haberal ${ }^{5}$, and \\ Sema Burgaz

\begin{abstract}
Department of Toxicology, Faculty of Pharmacyl, Department of Pediatric Nephrology', Department of General Surgery ${ }^{3}$, Faculty of Medicine, Gazi University, Department of Pediatric Nephrology ${ }^{4}$, Department of General Surgery, Faculty of Medicine, Baskent University, Ankara, Turkey
\end{abstract}

[Received in June 2016; CrossChecked in June 2016; Accepted in November 2016]

\begin{abstract}
The objective of this study was to reveal the likely genomic instability in children with chronic kidney disease (CKD) using micronucleus (MN) assay on buccal epithelial cells (BEC). We investigated the frequencies of micronuclei and other nuclear anomalies, such as nuclear buds, binucleated cells, condensed chromatin, and karyorrhectic and pyknotic cells in BEC. Children with CKD were grouped as follows: children in the pre-dialysis (PreD) stage ( $N=17)$, children on regular haemodialysis (HD) $(\mathrm{N}=14)$, and children who have undergone transplantation ( $\mathrm{Tx})(\mathrm{N}=17)$. As a control group, twenty age- and gender-matched healthy children were selected. The MN frequency in BEC of all groups of children with CKD was significantly elevated (5- to 7 -fold) as compared to the control group $(p<0.001)$. In contrast, the frequencies of nuclear buds were not significantly higher in the study groups compared to the control group. The frequencies of binucleated cells and condensed chromatin cells were significantly higher in all subgroups of children with CKD relative to the control group $(p<0.001)$. Our results show that the BEC of pediatric PreD, HD, and Tx patients with CKD display increased cytogenetic, cytokinetic, and cytotoxic effects. They also point to the sensitivity and usefulness of the BEC MN assay in the assessment of genetic susceptibility of patients with CKD.
\end{abstract}

KEY WORDS: buccal micronucleus assay; genotoxicity; dialysis; renal transplantation; nuclear anomalies

Chronic kidney disease (CKD) is a major public health concern (1). Recent reviews indicate that the adverse healthrelated outcomes of CKD and/or end-stage renal disease (ESRD) are characterised by high incidences of cardiovascular morbidity and mortality (2), liver damage due to viral infections (3), chronic inflammation (4), oxidative stress (5), and an increased incidence of cancer $(6,7)$.

Extensive research is still required to clarify the mechanisms underlying these outcomes of CKD and treatments like haemodialysis and transplantation. The causes, development, and treatment of CKD in paediatric patients differ from those in adult patients (8). Long periods of haemodialysis treatment have been linked to DNA damage, mainly due to oxidative stress (9). In adult patients with CKD, increased cancer incidence and cytogenetic effects in peripheral lymphocytes have been observed (7). In addition, the patient's susceptibility to neoplastic disorders increased as a consequence of prolonged immunosuppression after transplantation (10).

\footnotetext{
Correspondence to: Sema Burgaz, Department of Toxicology, Faculty of Pharmacy, Gazi University, Ankara, Turkey, Tel: +90 3122023087 , Fax: +90 312222 2326, Email: burgaz@gazi.edu.tr
}

Latency periods in most types of cancer are usually 15-20 years or longer, and conducting prospective epidemiological studies over long time periods is not always practical. Therefore, it is necessary to use the known biomarkers of DNA damage resulting from genetic instability to predict cancer risks and to identify high-risk individuals (11). Cytogenetic biomarkers are the most frequently used end points in human studies. In addition to peripheral blood lymphocytes, measurements of MN frequencies as well as other nuclear anomalies in buccal epithelial cells are increasingly used in molecular epidemiologic studies to investigate the impact of nutrition, lifestyle factors, genotoxic exposures, and genotype on DNA damage and cell death (12-14).

Studies from our laboratory $(15,16)$ have recently demonstrated significant increases in $\mathrm{MN}$ frequencies and basal DNA damage (determined by comet assay) in peripheral blood lymphocytes of children with CKD.

To the best of our knowledge, no genotoxicity studies of buccal cells of children with CKD have been reported so far. Therefore, we decided to investigate the frequencies of MN and other nuclear anomalies, such as nuclear buds (NBs), binucleated cells (BN), condensed chromatin (CC), karyorrhectic (KR), and pyknotic (PK) cells, in buccal epithelial cells (BEC) in children with CKD. There were

*These authors contributed equally to this work. 
three groups: children in the pre-dialysis (PreD) stage, children on regular hemodialysis (HD), and children who have had transplantation (Tx).

This study aims to reveal the possible genomic instability of CKD alone and treatment-related genotoxic and other effects (i.e. cytokinetic defects and cell death) in children with CKD using a non-invasive method: micronucleus assay on buccal tissue.

\section{SUBJECTS AND METHODS}

\section{Study population}

The study group consisted of 48 children (age range: 2-19 years) diagnosed with CKD. All of them were also involved in our previous studies $(15,16)$, where the causes of primary kidney disease and medication(s) received were described in more detail. Of these children, 17 ( 9 males and 8 females) were in the pre-dialysis stage, 14 (6 males and 8 females) were on regular haemodialysis, and 17 (10 males and 7 females) had kidney transplantation.

The study groups were: the children with blood creatinine levels higher than $1 \mathrm{mg} \mathrm{dL}^{-1}$ and glomerular filtration rates (GFR) in the range of $15-90 \mathrm{~mL} \mathrm{~min}^{-1}$ were selected for PD group. HD group consisted of children who underwent regular haemodialysis treatment for four hours three times per week. Tx group consisted of children who underwent kidney transplantation and were under immunosuppressant treatment, as described in our previous study (16). The duration of being diagnosed with PreD, HD, and $\mathrm{Tx}$, expressed in months $( \pm \mathrm{SD})$ was $41.35 \pm 38.83$, $29.75 \pm 27.68$, and $22.35 \pm 19.43$, respectively.

For the purpose of the study, we selected non-smokers who had never consumed alcohol and who were without any malignancies. The matched control group consisted of 20 healthy children (11 males and 9 females; age range 4-18 years) who were free from medication and infection, as confirmed by face-to-face interviews with their parents.

This study was approved by the local ethical committee of the Başkent University, Faculty of Medicine (03/07/200707/39). Furthermore, the parents of all children gave their informed consent prior to involving their children in the study. Detailed questionnaire forms completed by the parents included age, height, weight, and education, cigarette smoking and environmental tobacco smoke (ETS) exposure, recent diagnostic X-ray examination (three months prior to the sampling), recent vaccination, sports activities of the children, and the use of vitamin supplementations. Moreover, for those children who were diagnosed with kidney disease, information regarding the kidney disease type, parameters, grade, treatment type, medication, and viral infection were completed by their physicians. The causes of primary kidney disease and medication received among children have also been described in detail elsewhere $(15,16)$.

\section{Biological sampling}

The sampling of buccal epithelial cells from both the CKD and control groups was done between 16 Jul 2008 and 29 Jul 2009. For each subject, we simultaneously collected BEC for the MN-assay and blood samples which had been used for the purposes of other genotoxicity studies. Thus, data on genotoxicity endpoints (e.g. micronucleus and comet) in peripheral lymphocytes and routine biochemical parameters of the same populations have been published elsewhere $(15,16)$.

Buccal epithelial cells were obtained by scraping both sides of the inside of the cheeks using pre-moistened wooden tongue depressors after the subjects had rinsed their mouths with water.

The collected cells were first smeared directly onto pre-cleaned and pre-moistened microscope slides and were then left to dry. Within the same day, the slides were transferred to the laboratory where they were further processed.

\section{MN assay in buccal epithelial cells}

Preparations of buccal epithelial cells were fixed in $80 \%$ methanol (Merck, Germany) and air-dried. Slides were stained by the Feulgen reagent (pararosaniline, Merck, Germany) and then counterstained with Fast Green (Merck, Germany) $(17,18)$.

Microscopy analyses were performed using a light microscope (Zeiss Axioscope 2, Goettingen, Germany) at 400x magnification and confirmed at 1000x magnification. The coded slides were evaluated blindly by a single scorer.

The identification criteria of $\mathrm{MN}$ and other nuclear anomalies, previously described by Thomas et al. (19), were followed. For each subject, a total of 2000 differentiated and basal cells were analysed for the presence of the MN frequency and micronucleated cell and other nuclear anomaly (nuclear buds, condensed chromatin, binucleated, karyorrhectic and pyknotic cells) frequencies. Karyolytic cells were not scored. Basal and differentiated cell frequencies were not evaluated. The frequency of each parameter has been expressed as per thousand (\%).

\section{Statistical analysis}

Data were analysed using SPSS for Windows, version 11.5 (SPSS Inc., Chicago, IL, United States). The ShapiroWilk test was used to determine whether the distributions of continuous variables were normal. The Levene test was used to evaluate the homogeneity of variances. The data for continuous variables were expressed as the means \pm standard deviations (SD) or medians (min.-max.), and for nominal variables as the number of cases and/or percentage (\%). Regarding the number of independent groups, the mean differences were compared by Student's t test or One-Way ANOVA. Where applicable, the Mann-Whitney U or Kruskal-Wallis tests were applied to compare the median values. When the $p$-values (from One-Way ANOVA or 
Kruskal-Wallis test statistics) were statistically significant, a post-hoc Tukey or Conover's multiple comparison test was applied to determine which groups differed. Where applicable, nominal data were evaluated by the Pearson Chi-square or Fisher's exact test.

Degrees of association between continuous variables were evaluated using the Spearman's rank correlation test. Correlation analyses were performed to explore the association (if any) between buccal $\mathrm{MN}$ frequencies in the study subjects and corresponding lymphocyte MN frequencies and routine biochemical parameters data from recent publications $(15,16)$. Stepwise linear regression analyses were used to define predictive factors and dependent variables (e.g. MN frequency in BEC, micronucleated cell frequency in BEC), nuclear buds, binucleated cells, condensed chromatin cells, karyorrhectic and pyknotic cells). For those dependent variables that were not normally distributed, log-transformation was applied via multiple linear regression analyses. Any variable determined by univariate tests to be statistically significant and clinically important was accepted as a candidate for the multivariable model. After adjusting for factors, such as age, gender, body mass index, smoking, X-ray exposure, drug usage, and sports activities, multiple linear regression analyses were performed to determine whether there were any statistically significant differences among the study groups. Coefficients of regression and $95 \%$ confidence intervals were calculated for all independent variables. A $p$-value of less than 0.05 was considered statistically significant.

\section{RESULTS}

The demographic characteristics of the children with CKD and control group have already been reported in our previously published studies $(15,16)$. Considering that the present study and both of the previously mentioned ones were conducted simultaneously, here we briefly report the most important results which could help the reader to better understand the results of the MN assay on BEC.

As reported previously $(15,16)$, age, gender, and duration of sports activities among the study groups did not significantly vary. X-ray exposure three months prior to the sampling was significantly higher in CKD subgroups. None of them had a dental radiography examination. Vaccinations within a year were significantly more frequent in CKD subgroups, except HD vs. control group. Exposure to environmental tobacco smoke was significantly lower in CKD subjects, and differences in CKD subgroups vs. control group were statistically significant $(p<0.05)$. The Tx group exhibited the highest BMI values, and these values were significantly different from the control and HD groups $(p<0.05)$. In each CKD subgroup, either the MN frequency or the micronucleated cell frequency in BEC was significantly ( 5 - to 7 - fold) elevated in comparison with the control group $(p<0.001$; Table 1$)$.

Cell anomalies also revealed differences between the groups of children studied. The frequency of nuclear buds in the study group was not significantly different from the control group (Table 1) even though the children in the HD subgroup demonstrated a $23 \%$ increase in this parameter. Binucleated cell frequencies were significantly higher in all CKD subgroups relative to the control group $(p<0.001$; Table 1). The $\%$ increases for binucleated cells were $79 \%$, $56 \%$, and $86 \%$ in the Pre-D, HD, and Tx subgroups, respectively.

Table $1 M N$ and other nuclear anomalies (\%o) (Mean $\pm S D)$ in buccal epithelial cells of children with CKD and control group

\begin{tabular}{|c|c|c|c|c|c|}
\hline \multirow{3}{*}{$\mathbf{N}$} & \multicolumn{4}{|c|}{ Children with CKD } & \multirow{2}{*}{ Control group } \\
\hline & TS & PreD & HD & $\mathbf{T x}$ & \\
\hline & 48 & 17 & 14 & 17 & 20 \\
\hline MN frequency in BEC (\%o) & $8.34 \pm 7.33$ & $8.32 \pm 8.54$ & $9.57 \pm 7.61$ & $7.35 \pm 5.95$ & $1.45 \pm 1.30 *$ \\
\hline $\begin{array}{l}\text { Micronucleated cell frequency } \\
\text { in BEC }(\%)\end{array}$ & $5.36 \pm 3.99$ & $5.09 \pm 4.22$ & $5.79 \pm 3.93$ & $5.29 \pm 4.03$ & $1.03 \pm 0.95 *$ \\
\hline Nuclear buds (\%o) & $0.33 \pm 0.43$ & $0.26 \pm 0.31$ & $0.43 \pm 0.58$ & $0.30 \pm 0.40$ & $0.33 \pm 0.29$ \\
\hline Binucleated cells $(\%)$ & $30.66 \pm 9.20$ & $31.32 \pm 7.29$ & $27.43 \pm 7.99$ & $32.65 \pm 11.39$ & $17.55 \pm 5.25^{*}$ \\
\hline Condensed chromatin cells (\%) & $20.93 \pm 8.49$ & $24.18 \pm 12.12$ & $20.36 \pm 6.17$ & $18.15 \pm 3.77$ & $8.75 \pm 3.70^{*}$ \\
\hline Karyorrhectic cells (\%o) & $8.23 \pm 5.70$ & $9.00 \pm 5.34$ & $11.21 \pm 6.94$ & $5.00 \pm 2.91 * * *$ & $3.25 \pm 1.97 * *$ \\
\hline Pyknotic cells (\%o) & $24.41 \pm 14.83$ & $29.18 \pm 16.82$ & $29.04 \pm 11.28$ & $15.82 \pm 11.76^{* * *}$ & $14.55 \pm 6.17 * *$ \\
\hline
\end{tabular}

Abbreviations: $T S=$ total study group of children with disease and under treatment; Pre $D=$ children in predialysis; $H D=$ children in hemodialysis; Tx=children who underwent renal transplantation. ${ }^{*} \mathrm{p}<0.001$; control group $\mathrm{vs}$. TS, PreD, HD, and Tx. ${ }^{* *} \mathrm{p}<0.05$; control group vs. TS, PreD and HD. ***p<0.05; Tx vs. PreD and HD 
Table 2 Results on the multiple linear regression analysis of MN frequency and micronucleated cell frequency in BEC of study subjects (patients+controls, $N=68$ )

\begin{tabular}{lccc}
\hline & PreD & HD & Tx \\
\hline MN frequency $\left(\mathbf{R}^{2}=\mathbf{0 . 6 1 7}\right)$ & 1.418 & 1.573 & 1.474 \\
\hline$p$ & 0.000 & 0.002 & 0.001 \\
\hline B $(95 \%$ CIs $)$ & $(0.683$ to 2.152$)$ & $(0.612$ to 2.534$)$ & $(0.665$ to 2.283$)$ \\
\hline Micronucleated cell frequency $\left(\mathbf{R}^{2}=\mathbf{0 . 6 3 4}\right)$ & 1.271 & 1.489 & 1.421 \\
\hline$p$ & 0.000 & 0.001 & 0.000 \\
\hline B $(95 \%$ CIs $)$ & $(0.625$ to 1.917$)$ & $(0.644$ to 2.333) & $(0.710$ to 2.132) \\
\hline
\end{tabular}

Independent variables: Tx group, HD group, PreD group, age, gender, BMI, environmental tobacco smoke exposure, sports activity (hours), use of vitamin (yes/no), X-ray exposure, antihypertensive drugs, erythropoietin, osteoporosis drugs, antibiotics, iron drugs, phosex. Abbreviations: $C I s=$ confidence intervals, $B=$ regression coefficient (slope)

Significantly increased frequencies of condensed chromatin were found in each subgroup of children with CKD $(p<0.001$; Table 1)

Frequencies of karyorrhectic and pyknotic cells were significantly higher in the PreD and HD subgroups compared to the control group $(p<0.05$; Table 1$)$. However, the frequencies of karyorrhectic and pyknotic cells in the Tx group were significantly lower than those in the PreD and HD groups $(p<0.05$; Table 1$)$, and exhibited no significant differences relative to the control group.

Regression analysis indicates that every patient subgroup exhibited significant increases in buccal MN frequencies as well as micronucleated cell frequencies compared to control values ( $p<0.01$; Table 2$)$. This increase in the $\mathrm{MN}$ frequency was the highest for the $\mathrm{HD}$ subgroup $(\mathrm{B}=1.573, p=0.002)$, followed by the Tx $(\mathrm{B}=1.474$, $p=0.001)$ and $\operatorname{PreD}(\mathrm{B}=1.418, p=0.000)$ subgroups, respectively. The same trend was observed with regard to BEC micronucleated cell frequencies (Table 2).

A PreD or HD status significantly influenced condensed chromatin and pyknotic cell frequencies in $\operatorname{BEC}(p<0.01$; Table 3), whereas a Tx status significantly influenced condensed chromatin cell frequencies and binucleated cells in BEC $(p<0.01$, Table 3$)$. The effect on the frequencies of condensed chromatin cells was the highest in the PreD group $(\mathrm{B}=18.471, p<0.00001)$, followed by the HD $(\mathrm{B}=15.045, p<0.00001)$ and $\mathrm{Tx}(\mathrm{B}=12.154, p=0.001)$ groups, respectively (Table 3 ), while the effect on the frequencies of pyknotic cells was the highest in the HD group ( $\mathrm{B}=20.353, p=0.003)$, followed by the PreD group $(\mathrm{B}=16.993, p=0.001)$ (Table 3). A significant effect on the frequencies of binucleated cells was only observed for the Tx group $(\mathrm{B}=12.915, \mathrm{p}=0.007)$ (Table 3 ).

Diagnostic $X$-ray examination had a significant negative effect on the frequencies of condensed chromatin $(\mathrm{B}=-7.735$ $p<0.00001)$ and a positive significant effect on the frequencies of nuclear buds $(\mathrm{B}=0.272, p<0.05)$. Other independent variables, such as age, gender, BMI, ETS exposure, sports activity (hours), vitamin usage (yes/no), routine biochemical parameters and medication usage, had no significant effect on MN frequencies or nuclear anomalies (Tables 2 and 3). When patients and control subjects were taken as a whole, correlation analysis showed significant differences regarding the $\mathrm{MN}$ frequencies in $\mathrm{BEC}$ and routine biochemical parameters, such as creatinine, BUN, parathyroid hormone, ferritin, albumin, uric acid ( $\mathrm{r}=0.653, \mathrm{r}=0.616, \mathrm{r}=0.600, \mathrm{r}=0.534, \mathrm{r}=-0.450$, $\mathrm{r}=0.436$, respectively; $p<0.00001$ ), homocysteine, triglycerides, CRP, total protein, haematocrit, calcium and total cholesterol levels $(\mathrm{r}=0.408, \mathrm{r}=0.365, \mathrm{r}=0.336, \mathrm{r}=-$ $0.306, \mathrm{r}=-0.302, \mathrm{r}=-0.292, \mathrm{r}=0.254$, respectively; $p<0.05$ ). Similar correlations were obtained with regard to micronucleated cell frequencies in BEC.

Correlation analyses showed significant differences between the frequencies of nuclear anomalies in BEC and routine biochemical parameters. There was a significant correlation between the nuclear bud frequencies and ALT $(\mathrm{r}=0.387, p<0.05)$. The frequency of binucleated cells was significantly correlated to triglycerides $(\mathrm{r}=0.300$, $p<0.00001$ ), creatinine, BUN, total cholesterol, CRP, ferritin, homocysteine, parathyroid hormone, and uric acid levels $(\mathrm{r}=0.445, \mathrm{r}=0.260, \mathrm{r}=0.361, \mathrm{r}=0.265, \mathrm{r}=0.342$, $\mathrm{r}=0.253, \mathrm{r}=0.426, \mathrm{r}=0.268$, respectively; $p<0.05$ ). Significant correlations were also obtained between the condensed chromatin cell frequency and creatinine, BUN, triglycerides, and parathyroid hormone levels $(\mathrm{r}=0.523, \mathrm{r}=0.542, \mathrm{r}=0.595$, $\mathrm{r}=0.609$, respectively; $p<0.00001$ ) as well as total cholesterol, albumin, ferritin, homocysteine, alkaline phosphatase, and uric acid levels $(\mathrm{r}=0.292, \mathrm{r}=-0.247$, $\mathrm{r}=0.410, \mathrm{r}=0.403, \mathrm{r}=0.340, \mathrm{r}=0.348$, respectively; $p<0.05$ ). Significant correlations between karyorrhectic cell frequencies and creatinine, BUN, and triglyceride levels $(\mathrm{r}=0.555, \mathrm{r}=0.549, \mathrm{r}=0.595$, respectively; $p<0.00001)$, as well as albumin, ferritin, homocysteine, parathyroid hormone, and potassium levels $(\mathrm{r}=-0.313, \mathrm{r}=0.263, \mathrm{r}=0.361$, $\mathrm{r}=0.369, \mathrm{r}=0.299$, respectively; $p<0.05$ ) were also found. Pyknotic cell frequencies also correlated with creatinine, BUN, iron, parathyroid hormone, and sodium levels $(\mathrm{r}=0.374, \mathrm{r}=0.385, \mathrm{r}=0.318, \mathrm{r}=0.260, \mathrm{r}=-0.293$, respectively; $\mathrm{p}<0.05$ ).

There was a significant correlation between the $\mathrm{MN}$ frequency in BEC and the MN frequency in peripheral lymphocytes (in the whole study population; $\mathrm{r}=0.609$; $p=0.000$ ). A similar significant correlation was found with regard to the micronucleated cell frequency in BEC $(\mathrm{r}=0.613 ; p<0.00001)$. 


\section{DISCUSSION}

Recent data from the Turkish Society of Nephrology (20) reported 1643 haemodialyses, 2325 peritoneal dialyses, and 546 transplantations in children in our country. The increasing numbers of CKD patients and concurrently developing secondary diseases (especially cancer) indicate the importance of understanding this chronic disease, both in Turkey and all over the world. Children with CKD have an increased incidence of cancer (21), which is about ten times more frequent compared to healthy children of the same age (22). Thus, long-term survival and preventive strategies are crucial for children who have CKD and are undergoing treatment (23). Immunosuppressive drugs used to prevent graft rejection in recipients of kidney transplants and/or prolonged haemodialysis treatments have been linked to DNA damage and malignancies $(8,24)$.

Previous studies on chromosomal and/or DNA damage resulting from $\mathrm{CKD}$ and its treatment modes were based on adults. The biomarkers used in these studies were micronuclei in peripheral blood lymphocytes (PBL) (7, 25-27) and BEC (9), chromosome aberrations and sister chromatid exchanges $(28,29)$, and DNA strand breaks (comet assay) (26-28, 30, 31). The only reports regarding children with CKD were our recent studies using the MN and comet assays in PBL of children $(15,16)$.

Although PBL are generally accepted as appropriate surrogate tissue for biomarker studies, exfoliated epithelial cells, such as buccal, nasal, or urothelial cells constitute an alternative option, especially because the latter can be obtained with non-invasive methods. Over $90 \%$ of cancers occur in epithelial tissues, and, in many cases, epithelial tissues are the actual targets of carcinogens (32). The time required for BEC cells to migrate from the oral cavity to the basal layer is approximately 1-3 weeks (33). There are no definitive data regarding the cell turnover rates of buccal cells that influence a patient's disease status and/or the effects of several treatment chemicals. Nonetheless, we used this tissue to determine the short-term effects of exposures and/or disease-treatment status, in part because it is the most easily accessible tissue (particularly for children).

Recent meta-analysis results (34) suggest that the MN frequency in BEC can be used in the prescreening and follow-up of precancerous oral lesions and may reflect the chromosomal instability of other organs. Increased buccal $\mathrm{MN}$ frequencies have also been observed in small-sized studies on patients with chronic diseases, with Alzheimer's disease and Down syndrome (34). Scoring MN and other nuclear anomalies such as nuclear buds (for DNA damage), binucleated cells (for cytokinetic defects), condensed chromatin, and karyorrhectic and pyknotic (for cell death) cells in BEC, known as the cytome approach, has also been found to be associated with Down syndrome and Alzheimer's disease (19). Though there have been a limited number of studies on nuclear anomalies other than the MN frequency, it has been suggested that the cytome approach may improve the predictive value of the MN assay in BEC (34).

Therefore, using the cytome approach in BEC, the monitoring of children with CKD alone and treatmentrelated effects can be of particular significance.

In the present study, cytogenetic, cytokinetic, and cytotoxic (cell death) effects in the BEC of children

Table 3 Results on the multiple linear regression analysis of other nuclear anomaly frequencies in BEC of study subjects (patients + controls, $N=68$ )

\begin{tabular}{|c|c|c|c|c|}
\hline & PreD & HD & $\mathbf{T x}$ & $\mathrm{X}$-ray exposure \\
\hline Nuclear buds $\left(R^{2}=0.279\right)$ & -0.203 & -0.298 & -0.322 & 0.272 \\
\hline$p$ & 0.162 & 0.143 & 0.072 & 0.021 \\
\hline B (95\% CIs) & $(-0.490$ to 0.084$)$ & $(-0.699$ to 0.104$)$ & $(-0.674$ to 0.030$)$ & $(0.042$ to 0.502$)$ \\
\hline Binucleated cells $\left(R^{2}=0.531\right)$ & 7.748 & 7.052 & 12.915 & -0.513 \\
\hline$p$ & 0.110 & 0.199 & 0.007 & 0.857 \\
\hline B (95 \% CIs) & $(-1.831$ to 17.327$)$ & $(-3.867$ to 17.972$)$ & (3.750 to 22.080$)$ & $(-6.216$ to 5.189$)$ \\
\hline $\begin{array}{l}\text { Condensed chromatin cells } \\
\left(R^{2}=\mathbf{0 . 5 8 2}\right)\end{array}$ & 18.471 & 15.045 & 12.154 & -7.735 \\
\hline$p$ & 0.000 & 0.000 & 0.001 & 0.000 \\
\hline B (95 \% CIs) & (12.932 to 24.010$)$ & (8.320 to 21.770$)$ & (5.352 to 18.955$)$ & $(-11.837$ to- 3.634$)$ \\
\hline Karyorrhectic cells $\left(\mathrm{R}^{2}=\mathbf{0 . 4 8 8}\right)$ & 3.010 & 3.425 & -1.589 & -0.448 \\
\hline$p$ & 0.180 & 0.265 & 0.480 & 0.746 \\
\hline B (95\% CIs) & $(-1.432$ to 7.452$)$ & $(-2.670$ to 9.520$)$ & (-6.068 to 2.890$)$ & $(-3.208$ to 2.311$)$ \\
\hline Pyknotic cells $\left(\mathrm{R}^{2}=\mathbf{0 . 3 8 4}\right)$ & 16.993 & 20.353 & 4.994 & -6.988 \\
\hline$p$ & 0.001 & 0.003 & 0.373 & 0.073 \\
\hline $\mathrm{B}(95 \% \mathrm{CIs})$ & (7.485 to 26.500$)$ & (7.250 to 33.456$)$ & (-6.167 to 15.156$)$ & $(-14.652$ to 0.675$)$ \\
\hline
\end{tabular}

Independent variables: Tx group, HD group, PreD group, age, gender, BMI, environmental tobacco smoke exposure, sports activity (hours), use of vitamin (yes/no), X-ray exposure, antihypertensive drugs, osteoporosis drugs, antibiotics, shohl solution, other drugs, triglycerides, parathyroid hormone. Abbreviations: $C I s=$ confidence intervals, $B=$ regression coefficient (slope) 
diagnosed with CKD were clearly observed in the PreD stage and during treatment (HD and Tx), in agreement with our recent studies on peripheral lymphocytes $(15,16)$. In the scientific literature, we could not find any study in which the BEC MN assay has been used for children with CKD. In fact, only Roth et al. (9) have used the BEC MN assay in adults with CKD. This study reported higher MN frequencies for HD patients, which supports the findings of our study. These authors also indicated that the duration of treatment was a significant factor (9).

In our study, a cell death effect was shown in the PreD and HD groups, while in the Tx group only condensed chromatin was observed (Table 1). Karyorrhectic and pyknotic cell frequencies were not different for the Tx group compared to control group children. This might be because, compared to the PreD and HD groups, most of the CKD biochemical parameters improved in the Tx-group children (15). Uremic toxins, reactive carbonyl compounds, longterm haemodialysis treatment and the accumulation of advanced glycation end-products (AGEs) may be responsible for the effects observed in the PreD and HD groups, due to their suppression of DNA repair (35). Because the cellular anomalies reflecting the cytokinetic and cytotoxic effects in BEC were not comprehensively determined via the mechanistic approach, our interpretation of the data could be rather speculative.

Nuclear buds are considered to be a biomarker for the elimination of amplified DNA and/or DNA repair complexes and thus thought to play an important role in tumour progression (36). In our study, nuclear buds were the only parameter that showed no significant differences between patients and controls. A similar result was also found for nuclear buds in the PBL MN assay performed in the same subjects (16). Therefore, it is possible to link CKD and treatment statuses in children to genome damage. In the same subjects, the MN frequencies in lymphocytes correlated with those in BEC suggesting that the assessments of BEC and lymphocytes may complement each other. Considering the The HUman MicroNucleus project on eXfoLiated buccal cells $\left(\mathrm{HUMN}_{\mathrm{XL}}\right.$ ) project directions (37), more studies could be useful to prove the relationship between lymphocytes and BEC and to determine whether $\mathrm{BEC}$ may be used to predict the risk of cancer.

Considering that involvement in the PreD, HD, or Tx subgroups was the most significant factor linked to increased $\mathrm{MN}$ frequencies, as well as nuclear anomalies in the BEC of CKD children, an observation that supports the link between genetic instability and the development and treatment of this chronic disease is evident. Additionally, the significant associations observed among the biochemical parameters of CKD and BEC assay parameters further support this association. Also, a higher frequency of binucleated BEC observed in the present study and lower nuclear division index (NDI) in PBL (16) in the Tx group could be a signal of genome instability and cytokinetic defects that need further clarification.
It is known that several factors, such as age, gender, smoking, alcohol intake, and dietary habits, may contribute to spontaneous MN levels in exfoliated buccal cells (14). However, due to the limitations of the associated studies, the most important confounding factors have not yet been determined. These issues have recently been addressed in two review articles $(14,38)$.

The consistencies in age and gender between the study and control groups and the participation of non-smokers in the present study eliminated the most crucial of these confounding factors.

From a clinical point of view, diagnostic X-ray exposure in children and adults with CKD unavoidably occurred during their medical surveillance. Of course, this issue was also acknowledged by the clinician authors of our study. In the available literature, there are no cytogenetic effect studies on CKD which presented the X-ray exposure data of their populations. In the present study, $41.6 \%$ of children with CKD had an X-ray exposure history (mostly chest radiography) in the last three months prior to the biological sampling. Therefore, as explained in the statistical analysis section, multiple regression analysis was performed after adjusting for factors such as X-ray exposure, age, gender, body mass index, smoking, drug usage, and sports activities (Tables 2, 3). Accordingly, X-ray exposure issue seemed to have no apparent confounding effect on buccal MN frequencies. Similar results have also been demonstrated in peripheral lymphocytes of the same children with CKD $(15,16)$. On the other hand, the X-ray exposure effect on nuclear anomalies other than $\mathrm{MN}$, a positive X-ray effect, was only found for the formation of nuclear buds in BEC, while negative X-ray effects were found for condensed chromatin cells in BEC. The previously published studies that have investigated directly the effects of several radiographic and cephalographic techniques in dental practices (e.g. panoramic dental radiography, lateral cephalography, post anterior cephalography, and full-mouth $\mathrm{X}$-ray) on the target tissue BEC collected ten days after $\mathrm{X}$-ray exposure, which is the likely maximal rate of $\mathrm{MN}$ occurrence, have linked X-ray exposure to cytotoxicity but not genotoxicity determined as MN frequencies (39-42). In all these studies, an X-ray dose was between $0.003 \mathrm{mSv}$ and $0.02 \mathrm{mSv}(1-4)$. Choi (2011) compared the panoramic radiography for oral examination $(0.014-0.024)$ to the effective doses of chest radiography $(0.06-0.25 \mathrm{mSv}$ in two views) and looked at variability (43). Therefore, the type, dose, target tissue, target tissue turnover of X-ray exposure, and time after exposure are crucial parameters. From this point of view, the interpretation of the X-ray exposure effect as a confounding factor in biomonitoring studies is quite difficult and providing detailed information and statistical analysis could be the appropriate approach, as we have done in this study. Obviously, the association between the ionising radiation effects and outcomes of buccal micronucleus assay has to be more extensively evaluated in future biomonitoring studies, in contrast with 
micronucleus assay on lymphocytes, for which this association has nowadays been fairly well established (44).

From several previously published studies (45-49), including the one conducted in our laboratory, the 46 buccal $\mathrm{MN}$ frequencies reported for healthy children ranged from 0.10 to $4.03 \%$. The mean MN frequency for our control subjects $(1.45 \%)$ fell in that range. However, in our previous study, the background level variability observed in the buccal cells of healthy subjects (49) confirmed the need for method standardisation, which is an initiative of the $\mathrm{HUMN}_{\mathrm{xL}}$ project (37). When frequencies of nuclear anomalies of condensed chromatin and karyorrhectic and pyknotic cells were compared in different healthy children populations, large variabilities were observed. While some of them $(40,50)$, including our study, had much higher values, others (51) had lower values than the levels obtained in the study by Thomas et al. (52). The causes of this variability may, in part, reflect genetic and non-specific exposure differences, or in part, technical factors and differences in the sample preparation and interpretation of the scoring criteria between laboratories. Therefore, it was suggested that an automated scoring system should be developed to overcome this issue (53).

\section{CONCLUSION}

Increased cytogenetic, cytokinetic, and cytotoxic effects have been found in the buccal epithelial cells of children with CKD who underwent different treatment modes. Both the disease and treatment of CKD contribute to increased cytogenetic, cytokinetic, and cytotoxic effects on buccal epithelial cells of children. We believe that our data will add to the validation studies in the scope of the $\mathrm{HUMN}_{\mathrm{XL}}$ Project (37). Finally, they point to the sensitivity and usefulness of the BEC MN assay in the assessment of genetic susceptibility of patients with CKD.

\section{Funding}

This work was supported by the Gazi University Research Council [02/2007-22].

\section{Acknowledgements}

The authors are grateful to all of the children for their participation in this study. We would like to thank Mr. Salih Ergocen for performing statistical analyses.

\section{Declaration of interest}

The authors declare that they have no competing interests.

\section{REFERENCES}

1. Clark LE, Khan I. Outcomes in CKD: what we know and what we need to know. Nephron Clin Pract 2010;114:c95102. doi: $10.1159 / 000254381$
2. Wright J, Hutchison A. Cardiovascular disease in patients with chronic kidney disease. Vasc Health Risk Manag 2009;5:713-22. doi: 10.2147/VHRM.S6206

3. Fabrizi F, Messa P, Basile C, Martin P. Hepatic disorders in chronic kidney disease. Nat Rev Nephrol 2010;6:395-403. doi: 10.1038/nrneph.2010.37

4. Filiopoulos V, Hadjiyannakos D, Takouli L, Metaxaki P, Sideris V, Vlassopoulos D. Inflammation and oxidative stress in end-stage renal disease patients treated with hemodialysis or peritoneal dialysis. Int J Artif Organs 2009;32:872-82. PMID: 20037892

5. Kao MP, Ang DS, Pall A, Struthers AD. Oxidative stress in renal dysfunction: mechanisms, clinical sequelae and therapeutic options. J Hum Hypertens 2010;24:1-8. doi: $10.1038 / \mathrm{jhh} .2009 .70$

6. Schupp N, Schinzel R, Heidland A, Stopper H. Genotoxicity of advanced glycation end products: involvement of oxidative stress and of angiotensin II type 1 receptors. Ann N Y Acad Sci 2005;1043:685-95. doi: 10.1196/annals.1333.079

7. Stopper H, Treutlein AT, Bahner U, Schupp N, Schmid U, Brink A, Perna A, Heidland A. Reduction of the genomic damage level in haemodialysis patients by folic acid and vitamin B12 supplementation. Nephrol Dial Transplant 2008;23:3272-9. doi: 10.1093/ndt/gfn254

8. Coutinho HM, Groothoff JW, Offringa M, Gruppen MP, Heymans HSA. De novo malignancy after paediatric renal replacement therapy. Arch Dis Child 2001;85:478-83. doi: 10.1136/adc.85.6.478

9. Roth JM, Restani RG, Goncalves TTS, Sphor SL, Ness AB, Martino-Roth MG, Garcias GL. Genotoxicity evaluation in chronic renal patients undergoing hemodialysis and peritoneal dialysis, using the micronucleus test. Genet Mol Res 2008;7:433-43. PMID: 18551410

10. Agraharkar ML, Cinclair RD, Kou YF, Daller JA, Shahinian VB. Risk of malignancy with long-term immunosuppression in renal transplant recipients. Kidney Int 2004;66:383-9. doi: 10.1111/j.1523-1755.2004.00741.x

11. Fenech M. Biomarkers of genetic damage for cancer epidemiology. Toxicology 2002;181:411-6. doi: 10.1016/ S0300-483X(02)00480-8

12. Martins RA, Gomes GA, Aguiar OJr, Ribeiro DA. Biomonitoring of oral epithelial cells in petrol station attendants: comparison between buccal mucosa and lateral border of the tongue. Environ Int 2009;35:1062-5. doi: 10.1016/j.envint.2009.06.001

13. Burgaz S, Coskun E, Demircigil GC, Kocabas NA, Cetindag F, Sunter O, Edinsel H. Micronucleus frequencies in lymphocytes and buccal epithelial cells from patients having head and neck cancer and their first-degree relatives. Mutagenesis 2011;26:351-6. doi: 10.1093/mutage/geq101

14. Holland N, Bolognesi C, Kirsch-Volders M, Bonassi S, Zeiger E, Knasmueller S, Fenech M. The micronucleus assay in human buccal cells as a tool for biomonitoring DNA damage: the HUMN project perspective on current status and knowledge gaps. Mutat Res 2008;659:93-108. doi: 10.1016/j. mrrev.2008.03.007

15. Aykanat B, Demircigil GC, Fidan K, Buyan N, Gulleroglu K, Baskin E, Bayrakci US, Sepici A, Buyukkaragoz B, Karakayali H, Haberal M, Burgaz S. Basal and oxidative DNA damage in children with chronic kidney disease by comet assay. Mutat Res 2011;725:22-8. doi: 10.1016/j. mrgentox.2011.07.005 
16. Demircigil CG, Aykanat B, Fidan K, Gulleroglu K, Bayrakci US, Sepici A, Buyukkaragoz B, Karakayali H, Haberal M, Baskin E, Buyan N, Burgaz S. Micronucleus frequencies in peripheral blood lymphocytes of children with chronic kidney disease. Mutagenesis 2011;26:643-50. doi: 10.1093/mutage/ ger027

17. Stich HG, Rosin MP. Micronuclei in exfoliated human cells as tool for studies in cancer risk and cancer intervention. Cancer Lett 1984;22:241-53. doi: 10.1016/03043835(84)90159-9

18. Tolbert PE, Shy CM, Allen JW. Micronuclei and other nuclear anomalies in buccal smears: methods development. Mutat Res 1992;271:69-77. doi: 10.1016/0165-1161(92)90033-I

19. Thomas P, Holland N, Bolognesi C, Kirsch-Volders M, Bonassi S, Zeiger E, Knasmueller S, Fenech M. Buccal micronucleus cytome assay. Nat Protoc 2009;4:825-37. doi: 10.1038/nprot.2009.53

20. Serdengeçti K, Süleymanlar G, Altıparmak MR, Seyahi N. Registry of the nephrology, dialysis and transplantation in Turkey registry. In: Söylemezoğlu O, editor. Pediatric hemodialysis. Istanbul: Turkish Society of Nephrology, Pasifik Reklam ve Tanıtım Hizmetleri / Metris Matbaacılık; 2010. p. 37-53.

21. Schup N, Heidland A, Stopper H. Genomic damage in endstage renal disease contribution of uremic toxins. Toxins 2010;2:2340-58. doi: 10.3390/toxins 2102340

22. Groothoff JW. Long-term outcomes of children with endstage renal disease. Pediatr Nephrol 2005;20:849-53. doi: 10.1007/s00467-005-1878-9

23. Maisonneuve P, Agodoa L, Gellert R, Stewart JH, Buccianti G, Lowenfels AB, Wolfe RA, Jones E, Disney AP, Briggs D, McCredie M, Boyle P. Cancer in patients on dialysis for endstage renal disease: an international collaborative study. Lancet 1999;354:93-9. doi: 10.1016/S0140-6736(99)06154-1

24. Rath T, Oliveira-Frick V. Mutagenicity of immunosuppressive medications among renal transplant recipients. Am J Nephrol 2009;30:514-20. doi: 10.1159/000244646

25. Oliveira VD, Zanki H, Rath T. Mutagenic and cytotoxic effects of immunosuppressive drugs on human lymphocyte cultures. Exp Clin Transplant 2004;2:273-9. PMID: 15859941

26. Sandoval SB, Stoyanova E, Coll E, Pastor S, Reyes J, Andrés E, Ballarin J, Xamena N, Marcos R. Genetic damage in chronic renal failure patients is associated with the glomerular filtration rate index. Mutagenesis 2010;25:603-8. doi: 10.1093/mutage/geq047

27. Stoyanova E, Sandoval SB, Zúñiga LA, El-Yamani N, Coll E, Pastor S, Reyes J, Andrés E, Ballarin J, Xamena N, Marcos R. Oxidative DNA damage in chronic renal failure patients. Nephrol Dial Transplant 2010;25:879-85. doi: 10.1093/ndt/ gfp575

28. Buemi M, Floccari F, Costa C, Caccamo C, Belghity N, Campo S, Pernice F, Bonvissuto G, Coppolino G, Barillà A, Criseo M, Crascì E, Nostro L, Arena A. Dialysis-related genotoxicity: sister chromatid exchanges and DNA lesions in $\mathrm{T}$ and $\mathrm{B}$ lymphocytes of uremic patients. Genomic damage in patients on hemodiafiltration. Blood Purif 2006;24:569-74. doi: $10.1159 / 000097080$

29. Lialiaris T, Mavromatidou P, Digkas E, Passadaki T, Mpountoukas P, Panagoutsos S, Vargemezis V. Chromosome instability in patients with chronic renal failure. Genet Test
Mol Biomarkers 2010;14:37-41. doi: 10.1089/ gtmb.2009.0109

30. Kobras K, Schupp N, Nehrlich K, Adelhardt M, Bahner U, Vienken J, Heidland A, Sebekova K, Stopper H. Relation between different treatment modalities and genomic damage of end-stage renal failure patients. Kidney Blood Press Res 2006;29:10-17. doi: 10.1159/000092482

31. Stopper H, Boullay F, Heidland A, Vienken J, Bahner U. Comet-assay analysis identifies genomics damage in lymphocytes of uremic patients. Am J Kidney Dis 2001;38:296-301. doi: 10.1053/ajkd.2001.26094

32. Fenech M, Holland N, Chang WP, Zeiger E, Bonassi S. The human micronucleus project-an international collaborative study on the use of the micronucleus technique for measuring DNA damage in humans. Mutat Res 1999;428:271-83. doi: 10.1016/S1383-5742(99)00053-8

33. Stich HF, Rosin MP. Micronuclei in exfoliated human cells as an internal dosimeter for exposures to carcinogens. In: Stich HF, editor. Carcinogens and mutagens in the environment. Vol. II. Boca Raton (FL): CRC Press; 1983. p. $17-25$.

34. Bolognesi C, Bonassi S, Knasmueller S, Fenech M, Bruzzone M, Lando C, Ceppi M. Clinical application of micronucleus test in exfoliated buccal cells: A systematic review and metanalysis. Mutat Res Rev Mutat Res 2015;766:20-31. doi: 10.1016/j.mrrev.2015.07.002

35. Schupp N, Dette EM, Schmid U, Bahner U, Winkler M, Stopper H. Benfotiamine reduces genomic damage in peripheral lymphocytes of hemodialysis patients. Naunyn Schmiedebergs Arch Pharmacol 2008;378:283-91. doi: 10.1007/s00210-008-0310-y

36. Fenech M, Crott JW. Micronuclei, nucleoplasmic bridges and nuclear buds induced in folic acid deficient human lymphocytes-evidence for breakage-fusion-bridge cycles in the cytokinesis-block micronucleus assay. Mutat Res 2002;504:131-6. doi: 10.1016/S0027-5107(02)00086-6

37. Bonassi S, Coskun E, Ceppi M, Lando C, Bolognesi C, Burgaz S, Holland N, Kirsh-Volders M, Knasmueller S, Zeiger E, Carnesoltas D, Cavallo D, da Silva J, de Andrade VM, Demircigil GC, Domínguez Odio A, Donmez-Altuntas H, Gattas G, Giri A, Giri S, Gómez-Meda B, Gómez-Arroyo S, Hadjidekova V, Haveric A, Kamboj M, Kurteshi K, Martino-Roth MG, Montero Montoya R, Nersesyan A, Pastor-Benito S, Favero Salvadori DM, Shaposhnikova A, Stopper H, Thomas P, Torres-Bugarín O, Yadav AS, Zúñiga González G, Fenech M. The HUman MicroNucleus project on eXfoLiated buccal cells (HUMN(XL): The role of lifestyle, host factors, occupational exposures, health status, and assay protocol. Mutat Res 2011;728:88-97. doi: 10.1016/j. mrrev.2011.06.005

38. Ceppi M, Biasotti B, Fenech M, Bonassi S. Human population studies with the exfoliated buccal micronucleus assay: statistical and epidemiological issues. Mutat Res 2010;705:11-9. doi: 10.1016/j.mrrev.2009.11.001

39. Angelieri F, de Oliveira GR, Sannomiya EK, Ribeiro DA. DNA damage and cellular death in oral mucosa cells of children who have undergone panoramic dental radiography. Pediatr Radiol 2007;37:561-5. doi: 10.1007/s00247-0070478-1

40. Lorenzoni DC, Fracalossi AC, Carlin V, Ribeiro DA, Sant'anna EF. Cytogenetic biomonitoring in children submitting to a complete set of radiographs for orthodontic 
planning. Angle Orthod 2012;82:585-90. doi: $10.2319 / 072311-468.1$

41. Ribeiro DA, de Oliveira G, de Castro G, Angelieri F. Cytogenetic biomonitoring in patients exposed to dental $\mathrm{X}$-rays: comparison between adults and children. Dentomaxillofac Radiol 2008;37:404-7. doi: 10.1259/ $\mathrm{dmfr} / 58548698$

42. Cerqueira EM, Gomes-Filho IS, Trindade S, Lopes MA, Passos JS, Machado-Santelli GM. Genetic damage in exfoliated cells from oral mucosa of individuals exposed to $\mathrm{X}$-rays during panoramic dental radiographies. Mutat Res 2004;562:111-7. doi: 10.1016/j.mrgentox.2004.05.008

43. Choi J-W. Assessment of panoramic radiography as a national oral examination tool: review of the literature. Imaging $\mathrm{Sci}$ Dent 2011;41:1-6. doi: 10.5624/isd.2011.41.1.1

44. Milić M, Rozgaj R, Kašuba V, Jazbec A-M, Starčević B, Lyzbicki B, Ravegnini G, Zenesini C, Musti M, Hrelia P, Angelini S. Polymorphisms in DNA repair genes: link with biomarkers of the CBMN cytome assay in hospital workers chronically exposed to low doses of ionising radiation. Arh Hig Rada Toksikol 2015;66:109-120. doi: 10.1515/aiht-201566-2655

45. Ferreira FLS, Pra D, Martino-Roth MG, Garcias GL. Buccal micronucleus frequency is associated with age in Down syndrome. Genet Mol Res 2009;8:1231-7. doi: 10.4238/ vol8-4gmr636

46. Holland N, Harmatz P, Golden D, Hubbard A, Wu YY, Bae J, Chen C, Huen K, Heyman MB. Cytogenetic damage in blood lymphocytes and exfoliated epithelial cells of children with inflammatory bowel disease. Pediatr Res 2007;61:20914. doi: 10.1203/pdr.0b013e31802d77c7

47. Minicucci EM, Ribeiro DA, de Camargo B, Costa MC, Ribeiro LR, Salvador DMF. DNA damage in lymphocytes and buccal mucosa cells of children with malignant tumours undergoing chemotherapy. Clin Exp Med 2008;8:79-85. doi: 10.1007/s10238-008-0161-3

48. Ünal M, Çelik A, Ateş NA, Micozkadioğlu D, Derici E, Pata YS, Akbaş Y. Cytogenetic biomonitoring in children with chronic tonsillitis: Micronucleus frequency in exfoliated buccal epithelium cells. Int J Pediatr Otorhinolaryngol 2005;69:1483-8. doi: 10.1016/j.jporl.2005.04.002

49. Karahalil B, Karakaya AE, Burgaz S. The micronucleus assay in exfoliated buccal cells: application to occupational exposure to polycyclic aromatic hydrocarbons. Mutat Res 1999;442:29-35. doi: 10.1016/S1383-5718(99)00055-8

50. Ceretti E, Feretti D, Viola GC, Zerbini I, Limina RM, Zani C, Capelli M, Lamera R, Donato F, Gelatti U. DNA damage in buccal mucosa cells of pre-school children exposed to high levels of urban air pollutants. PLoS One 2014;9:e96524. doi: 10. 1371/ journal. pone.0096524

51. El-Ashiry EA, Abo-Hager EA, Gawish AS. Genotoxic effects of dental panoramic radiograph in children. J Clin Pediatr Dent 2010;35:69-74. doi: 10.17796/jcpd.35.1.y61382473 5287307

52. Thomas P, Harvey S, Gruner T, Fenech M. The buccal cytome and micronucleus frequency is substantially altered in Down's syndrome and normal ageing compared to young healthy controls. Mutat Res 2008;638:37-47. doi: 10.1016/j. mrfmmm.2007.08.012

53. Bolognesi C, Roggieri P, Ropolo M, Thomas P, Hor M, Fenech M, Nersesyan A, Knasmueller S. Buccal micronucleus cytome assay: results of an intra- and inter-laboratory scoring comparison. Mutagenesis 2015;30:545-55. doi: 10.1093/ mutage/gev017

\section{Mikronukleusi i ostala citogenetička oštećenja u epitelnim stanicama bukalne sluznice djece koja boluju od kroničnih bubrežnih bolesti}

Cilj ovoga istraživanja bio je utvrditi moguću genomsku nestabilnost u djece koja boluju od kroničnih bubrežnih bolesti (KBB). Korišten je mikronukleus (MN) test na epitelnim stanicama bukalne sluznice. Ispitivali smo učestalost mikronukleusa i ostalih citogenetičkih oštećenja poput jezgrinih pupova, binuklearnih stanica, kondenziranoga kromatina, kariorektičnih i piknotičnih stanica u stanicama bukalne sluznice. Djeca s KBB-om bila su podijeljena u sljedeće skupine: djeca u fazi prije dijalize (PreD) $(\mathrm{N}=17)$, djeca koja su redovito na hemodijalizi (HD) $(\mathrm{N}=14)$ i djeca s transplantiranim bubregom (Tx) $(\mathrm{N}=17)$. Kontrolnu skupinu činila su zdrava djeca iste dobi i spola. Učestalost $\mathrm{MN}$-a u stanicama bukalne sluznice u svim skupinama djece s KBB-om bila je značajno povećana (petero- do sedmerostruko) u usporedbi s kontrolnom skupinom $(p<0,001)$. Suprotno tome, učestalost jezgrinih pupova nije bila značajnije veća u promatranoj skupini $\mathrm{u}$ usporedbi s kontrolnom skupinom. Učestalost binuklearnih stanica i kondenziranoga kromatina bila je značajnije veća u svim podskupinama djece s KBB-om u odnosu na kontrolnu skupinu $(p<0,001)$. Naši rezultati upućuju ne samo na povećanu razinu citogenetičkih, citokinetičkih i citotoksičnih promjena u stanicama bukalne sluznice u djece PreD, HD i Tx skupina nego i na osjetljivost i korisnost MN-testa na stanicama bukalne sluznice u procjeni genetičke osjetljivosti pacijenata koji boluju od KBB-a.

KLJUČNE RIJEČI: citogenetička oštećenja, dijaliza; genotoksičnost; mikronukleus-test na stanicama bukalne sluznice; transplantacija bubrega 